\title{
Farklılaştırılmış Öğretim Yaklaşımının İlkokul Üçüncü Sınıf Öğrencilerinin Matematik Dersindeki Başarısına ve Tutumuna Etkisi*
}

\section{The Effect of Differentiated Instruction on Mathematical Attitudes and Achievements of Third Grade Primary School Learners}

\author{
Onur Ekinci a,** ${ }^{\text {a }}$, Ayten Pinar Bal ${ }^{\text {b }}$ \\ a. Uzman Öğretmen, Milli Eğitim Bakanlığı, Adana/Türkiye. \\ ORCID: 0000-0003-2694-9655 \\ b Doç. Dr., Çukurova Üniversitesi, Eğitim Fakültesi, Fen ve Matematik Eğitimi Bölümü, 01330, Adana/Türkiye \\ ORCID: 0000-0003-1695-9876
}

\section{MAKALE BILGİSI}

\section{Makale Geçmişi:}

Başvuru tarihi: 21 Eylül 2018

Düzeltme tarihi: 18 Ekim 2018

Kabul tarihi: 01 Kasım 2018

\section{Anahtar Kelimeler:}

Matematik Öğretimi

Matematik Başarısı

Farklılaștırılmış Öğretim Yaklaşımı

Matematiğe Yönelik Tutum

\section{A R T I CLE INFO}

\section{Article history:}

Received 21 September 2018

Received in revised form 18 October 2018

Accepted 01 November 2018

\section{Keywords:}

Mathematics education,

Mathematics Achievements

Differentiated Instruction method

Mathematical Attitudes

\section{ÖZ}

$\mathrm{Bu}$ araştırmanın amacı, farklılaştırılmış öğretim yaklaşımının ilkokul üçüncü sınıf öğrencilerinin matematik dersindeki başarılarına ve tutumlarına etkisini belirlemektir. Araştırma nicel araştırma yöntemlerinden ön test-son test kontrol gruplu yarı deneysel modele göre tasarlanmıştır. Araştırmanın çalışma grubunu Adana ili Ceyhan ilçesinin alt sosyo-ekonomik düzeyinde bulunan bir devlet ilkokulunun üçüncü sınıf öğrencileri oluşmaktadır. Veri toplama aracı olarak, "matematik başarı testi" ve "matematik tutum ölçeği" kullanılmıştır. Araştırmada, öğrencilerin deney öncesi ve sonrasındaki test puanlarını karşılaş̧ırmak amacıyla bağımsız grupla t testi Analizi kullanılmıştır. Araştırma sonunda elde edilen verilere göre, başarı testi son test ve kalıcılık puanları açısından deney grubu lehine istatistiksel olarak anlamlı bir fark bulunmuştur. Ancak deney grubundaki öğrencilerle, kontrol grubundaki öğrencilerin deney öncesi, sonrası ve kalıcılık tutum puanları arasında anlamlı bir fark olmadığı sonucuna ulaşılmıştır.

\section{A B S T R A C T}

This study has been carried out in order to define the effects of differentiated instruction method on the mathematical attitudes and achievements of primary school third grade learners. . It is designed on semi-experimental model with pretest and posttest control group. The population of the study consists of 3rd grade public primary school students educating at low socio-economic level in Ceyhan county of Adana province. The data has been collected by using "Mathematics Achievement Test" and "Mathematics Attitude Scale". In order to compare the test scores of the students before and after the experiment, an independent group t-test was used. According to the data obtained at the end of the study, a statistically significant difference was found in favor of the experimental group in terms of achievement test posttest and retention scores. However, it was concluded that there was no significant difference between the students in the experimental group and the students before and after the experime.

\section{Giriş}

Günümüzde bilim ve teknolojinin sürekli ilerleyerek değişmesi toplumsal yaşamın gereksinimlerini ve buna dair beklentileri de yükseltmiştir. Toplumun çağın gereksinimlerine uyum sağlaması ise, bireylerin çağdaş eğitimi ile mümkündür (Senemoğlu, 2002). Eğitim süreci öğrencilerde sadece bilgi aktarımı şeklinde değil, aynı zamanda düşündürme ve bilgi üretme şeklinde de gerçekleşir. $\mathrm{Bu}$ açıdan bakıldığında, öğrencilerin bağımsız

\footnotetext{
* Bu çalışma, 2016 yılında Çukurova Üniversitesi Sosyal Bilimler Enstitüsü tarafindan kabul edilen “Farklılaştırılmış öğretim yaklaşımının ilkokul üçüncü sinıf ögrrencilerinin matematik dersindeki başarısına ve tutumuna etkisi" adlı Yüksek Lisans tezinden türetilmiş; 3-6 Temmuz 2018 tarihlerinde İstanbul'da düzenlenen "International Conference on Mathematics: An Istanbul Meeting for World Mathematicians" Kongresi'nde bildiri olarak sunulmuş ve Çukurova Üniversitesi BAP birimi tarafindan SYL-2016-6708 proje no ile desteklenmiştir.

** Sorumlu yazar/Corresponding author.

e-posta: onurekinci12@gmail.com
} 
ve analitik düşünebilmesine; ayrıca geçmiş deneyimlerinden yola çıkarak bilgiyi kendisinin oluşturmasına olanak sağlayan bilim dalları arasında matematik ön sıralarda yer almaktadır (Kart, 2002). Ancak, literatürde yapılan çalışmalar, öğretim programlarında yer alan matematik konu alanlarının, içerik bakımından genelde bireysel farklılıkları göz önünde bulundurmadığını ve çoğunlukla öğrenme seviyelerini bütün öğrenciler için eşit gördüğüne işaret etmektedir (Arıkan \& Ünal, 2013; Aydın, 2014; Demirel, 2006; Açıkgöz, 2003). Başka bir ifade ile bütün öğrenciler, aynı zorluk derecesindeki konu üzerinde aynı şekilde öğrenmeye bir şekilde zorlanmaktadırlar $\mathrm{Bu}$ bağlamda, öğrencilerin bireysel farklılıklarını gözeten ve geleneksel öğretim yöntemlerinden farklı olarak bilginin pek çok düzeyde ve farklı bakış açılarıyla oluşturulmasını etkin kılan farklılaştırılmış öğretim yaklaşımları büyük önem kazanmakatdır (Gregory ve Chapman, 2002; Good, 2006; Uygun ve Tertemiz, 2014).

İlk kez Tomlinson (1999) tarafından ortaya konan farklılaştırılmış öğretim yaklaşımı, öğrenciyi merkeze alan çoklu zekâ kuramı, zihin temelli öğrenme kuramı ve oluşturmacılık gibi birçok modeli kapsar (Bosier, 2007; Stager, 2007). Farklılaştırılmış öğretim yaklaşımı farklı düzeylerde öğrenen öğrenciler için kaliteli ve nitelikli eğitim verilmesi için kullanılmaktadır (Abbati, 2012). Bu yaklaşım, aynı sınıfta farklı özelliklere sahip öğrencilerin öğrenme öğretme sürecidir (Hall, Meyer ve Strangman, 2010). Farklılaştırılmış öğretim yaklaşımı farklı öğrenen öğrencilerin ihtiyaçlarını karşılamak için öğrenme stillerine göre eğitim verilmesidir (Ericson, 2010). Öğrenci sayısını, ekstra zamanı, bireysel farklılıkları ve yetenekleri dikkate alarak eğitimin kaliteli yapılmasını sağlar (Abbati, 2012). Uygulandığı öğrenme ortamlarında öğrencilerin kendi gelişimlerine katk1 sağlar (Lawrence-Brown, 2004). Akademik olarak sorumluluğunu bilen sınıflar oluşturmak, eşitlik ve mükemmellik değerleri üzerine kurulmuş bir ülke için çok önemlidir (Tomlinson, 1999). Okullarımız bu değerleri öğrenme noktasında heterojen ancak, yüksek kaliteli bir program ve eğitim sistemi üzerine inşa edilmiş bir topluluk oluşturarak, her öğrencinin kapasitesini maksimum düzeye taşıyarak başarabilir (Tomlinson, 1999).

Farklılaştırılmış eğitimin amacı; öğrenmeye duyulan istek, ilgi alanları, dünyayı kendi kültürleri doğrultusunda görme ve yorumlama biçimleri ve deneyimleri açısından birbirinden çok farklı öğrencilerin sunduğu yelpaze içinde onlara en etkili biçimde ulaşmanın yolunu bulmaktır (Tomlinson, 1999). Bu bağlamda farklılaştırılmış eğitim öğrencilerin derin fikirlerle mücadele etmesine, önemli noktalarda öğrenmiş oldukları bilgileri kullanmalarına, fikirlerini ve bilgilerini organize etmelerine ve sınıf ortamında kazandıkları bilgi ve davranışları tüm hayatlarına transfer etmelerine yardımcı olur. Ayrıca farklılaştırılmış eğitim öğrencilerin analitik düşünebilmelerine, önemli noktalarda öğrenmiş oldukları bilgileri kullanmalarına, fikirlerini ve bilgilerini organize etmelerine ve sinıf ortamında kazandıkları bilgi ve davranışları tüm hayatlarına transfer etmelerine yardımcı olur (Tomlinson, 2000). Yine, bu yaklaşım, öğrenciyi merkeze alan, programın içeriğini keşfederek öğrenmesini sağlamak için öğrenme yaşantılarını öğrenci ihtiyaçlarına yönelik hazırlayan, öğrencinin dikkatini çeken, öğrencilerin kendi bilgi ve düşüncelerini anlamlandırmasını, oluşturmasını ve derse aktif katılımını sağlayan, öğrenenlerin öğrendiklerini uygulayacağı özgün bir ortam sunan öğrenme yaşantısı olarak da nitelendirilebilir (Hall, Strangman ve Meyer, 2010; Levy, 2008). Matematik konu alanı bağlamında farklılaştırılmış öğretim yaklaşımları ile ilgili literatür tarandığında, yapılan araştırmaların matematik öğretim programında yer alan sayılar ve geometri öğrenme alanları üzerine yoğunlaştığı (Abbati, 2012; Boerger, 2005; Bosier, 2007; Chamberlin ve Powers, 2010; Christensen, 2007; Ericson, 2010; Millikan, 2012); kesirler konusunda ise sınırlı sayıda (Karataş, 2013; Stager, 2007; Yabaş, 2008) araştırma yer aldığı göze çarpmaktadır. Örneğin, Yabaş (2008) tarafından yapılan araştırmada altıncı sınıf öğrencilerine farklılaştırılmış öğretim yaklaşımı uygulanarak matematik dersinin ondalı kesirler ünitesindeki başarılarının, biliş üstü becerilerinin ve öz yeterlilik algılarının etkisini incelemiştir. Araştırmayı deneysel desene göre ön test-son test sonuçlarına göre 25 öğrenciye uygulamışlardır. Araştırmaları sonucunda öğrenci başarılarının, becerilerinin ve yeterliliklerinin olumlu şekilde artığı ortaya çıkmıştır. Stager (2007) da kesirler konu alanı kapsamında yürüttüğü çalışmada, farklılaştırılmış öğretim yaklaşımının öğrenci başarısını ve tutumunu olumlu yönde arttırdığ 1 bulgusuna ulaşmıştır.

Yukarıda değinilen bilgiler 1şı̆̆ında, bu araştırma farklılaştırılmış öğretim yaklaşımının ilkokul üçüncü sınıf öğrencilerinin akademik başarı ve tutumları üzerindeki etkisini incelemek amacı ile yapılmıştır. $\mathrm{Bu}$ amaç doğrultusunda aşağıdaki araştırma sorularına yanıt aranmıştır:

(i) Farklılaştırılmış öğretim yaklaşımının uygulandığı deney grubu ile mevcut öğretimin uygulandığ kontrol grubundaki öğrencilerin, ön test puanları kontrol altına alındığında, son test puanları arasında anlamlı bir farklılık var mıdır?

(ii) Farklılaştırılmış öğretim yaklaşımının uygulandığı deney grubu ile mevcut ögretimin uygulandığ kontrol grubundaki öğrencilerin, son test puanları kontrol altına alındığında, kalıcılık test puanları arasında anlamlı bir farklılık var midır?

(iii) Farklılaştırılmış öğretim yaklaşımının uygulandığı deney grubu ile mevcut öğretimin uygulandığı kontrol grubundaki öğrencilerin, ön test tutum ölçeği puanları kontrol altına alındığında, son test tutum ölçeği puanları arasında anlamlı bir farklılık var midir?

(iv) Farklılaştırılmış öğretim yaklaşımının uygulandığ deney grubu ile mevcut öğretimin uygulandığ kontrol grubundaki öğrencilerin, son test tutum ölçeği puanları kontrol altına alındığında, kalıcılık test tutum ölçeği puanları arasında anlamlı bir farklılık var midir?

\section{Yöntem}

\subsection{Araştırma Modeli}

Matematik dersinde farklılaştırılmış öğretim yaklaşımının öğrencilerin başarı ve tutumuna etkisini belirlemek amacıyla yapılan bu çalışma, nicel araştırma yöntemlerinden ön testson test kontrol gruplu yarı deneysel modele göre tasarlanmıştır. Yarı deneysel model, bazı kontrol güçlüklerine bakarak, sınırlılıklarını önemle dikkate almak 
kaydıyla, gerçek deneme modellerinin uygulanmadığı durumlarda kullanılmaktadır (Karasar, 1999).

\subsection{Evren ve Örneklem}

Araştırmanın çalışma grubu Adana ili Ceyhan ilçesinde 2015-2016 eğitim öğretim y1lında bir devlet okulunda öğrenim gören ilkokul üçüncü sınıfta okuyan 40 öğrenciden oluşmaktadır. Araştırmanın yürütüleceği okulda bulunan üçüncü sınıflardan rastgele olarak seçilen şubelerden biri deney diğeri ise kontrol grupları olarak belirlenmiştir. Araştırmaya katılan deney ve kontrol grubundaki öğrencilerin cinsiyet, baba ve anne öğrenim düzeylerine ilişkin dağılım Tablo 1'de yer almaktadır.

Tablo 1. Deney ve Kontrol Gruplarındaki Öğrencilerin Cinsiyetleri Baba ve Anne Öğretim Durumlarına Göre Dağılımı

\begin{tabular}{|c|c|c|c|c|}
\hline \multirow{2}{*}{ Cinsiyet } & \multicolumn{2}{|c|}{ Deney } & \multicolumn{2}{|c|}{ Kontrol } \\
\hline & $\mathrm{f}$ & $\%$ & $\mathrm{f}$ & $\%$ \\
\hline $\mathrm{K}_{1} \mathrm{Z}$ & 14 & 70 & 11 & 55 \\
\hline Erkek & 6 & 30 & 9 & 45 \\
\hline \multirow[t]{2}{*}{ Toplam } & 20 & 100 & 20 & 100 \\
\hline & \multicolumn{2}{|c|}{$\mathrm{Sd}=1 \quad \mathrm{P}=.327$} & & \\
\hline \multirow{3}{*}{ Öğrenim Düzeyi } & \multicolumn{2}{|c|}{ Deney } & \multicolumn{2}{|c|}{ Kontrol } \\
\hline & \multicolumn{2}{|c|}{ Baba } & \multicolumn{2}{|c|}{ Baba } \\
\hline & $\mathrm{f}$ & $\%$ & $\mathrm{f}$ & $\%$ \\
\hline İlkokul Terk & 0 & 0 & 7 & 35.0 \\
\hline İlkokul & 12 & 60.0 & 9 & 45.0 \\
\hline Ortaokul & 1 & 5.0 & 1 & 5.0 \\
\hline Lise & 7 & 35.0 & 3 & 15.0 \\
\hline Toplam & 20 & 100 & 20 & 100 \\
\hline \multicolumn{5}{|c|}{$\mathrm{X}^{2}=1.240 \mathrm{Sd}=4 \mathrm{P}=.872$} \\
\hline \multirow{3}{*}{ Öğrenim Düzeyi } & \multicolumn{2}{|c|}{ Deney } & \multicolumn{2}{|c|}{ Kontrol } \\
\hline & \multicolumn{2}{|c|}{ Anne } & \multicolumn{2}{|c|}{ Anne } \\
\hline & $\mathrm{f}$ & $\%$ & f & $\%$ \\
\hline İlkokul Terk & 5 & 25.0 & 9 & 45.0 \\
\hline İlkokul & 10 & 50.0 & 9 & 45.0 \\
\hline Ortaokul & 0 & 0 & 1 & 5.0 \\
\hline Lise & 5 & 25.0 & 1 & 5.0 \\
\hline Toplam & 20 & 100 & 20 & 100 \\
\hline
\end{tabular}

Tablo 1 incelendiğinde deney grubundaki öğrencilerin \%70’i k1z, \%30'u ise erkektir. Kontrol grubundaki öğrencilerin ise $\% 55^{\prime} \mathrm{i} \mathrm{k1z}$ ve $\% 45^{\prime} \mathrm{i}$ erkektir. Diğer taraftan deney grubundaki öğrencilerin babalarının öğrenim durumları incelendiğinde $\% 60$ 'nın ilkokul, \%5'nın ortaokul, \%35'inin lise mezunu olduğu görülmektedir. Kontrol grubundaki öğrencilerin babalarının öğrenim durumları incelendiğinde ise \%35'inin ilkokul terk, \%45'inin ilkokul, \%5'inin ortaokul, \%15'inin lise mezunu olduğu görülmektedir. Son olarak deney grubundaki öğrencilerin annelerinin öğrenim durumları incelendiğinde bu kişilerin \%25'inin ilkokul terk, $\% 50$ 'sinin ilkokul ve \%25'inin ise lise mezunu olduğu görülmektedir. Kontrol grubundaki öğrencilerin annelerinin öğrenim durumları incelendiğinde ise bu kişilerin $\% 45$ 'inin ilkokul terk, \%45'inin ilkokul, \%5'inin ortaokul ve \%5'inin ise lise mezunu olduğu görülmektedir. Ayrıca yapılan kay kare analiz sonucuna göre de cinsiyet açısından $\left[\left(\mathrm{X}^{2}=.96\right.\right.$ $\mathrm{sd}=1, \mathrm{p}=.327)]$; baba eğitim durumu açısından $\left[\left(\mathrm{X}^{2}=1.240\right.\right.$ $\mathrm{sd}=4, \mathrm{p}=.872)]$ ve anne eğitim durumu açısından $\left[\left(\mathrm{X}^{2}=0.098\right.\right.$ $\mathrm{sd}=3, \mathrm{p}=.992)]$ istatistiksel olarak anlamlı bir fark olmadığ görülmektedir.

\subsection{Veri Toplama Arac1}

Araştırmada veri toplama araçları olarak; üçüncü sınıf matematik dersi, "kesirler" konusuna ilişkin "matematik başarı testi" ve "matematik tutum ölçeği”" kullanılmıştır. Bu kapsamda öncelikle deneysel işlem öncesine dair veriler toplanmış daha sonra ise deneysel işlem sonrası veriler toplanmıştır.

Tablo 2. Matematik Başarı Testinin Madde Güçlük İndisleri (pj), Standart Sapmaları (sj), Ayırıcılık İndisleri (rjx), t ve p Değerleri

\begin{tabular}{|c|c|c|c|c|c|}
\hline Madde No & $\mathrm{pj}$ & $\mathrm{sj}$ & rjx & $\mathrm{t}$ & $\mathrm{p}$ \\
\hline 1 & .61 & .49 & .53 & -5.501 & .000 \\
\hline 2 & .57 & .50 & .52 & -6.052 & .000 \\
\hline 3 & .69 & .46 & .41 & -4.460 & .000 \\
\hline 4 & .42 & .47 & .48 & -4.754 & .000 \\
\hline 5 & .63 & .49 & .37 & -3.325 & .002 \\
\hline 6 & .72 & .45 & .27 & -2.938 & .005 \\
\hline 7 & .64 & .48 & .43 & -5.346 & .000 \\
\hline 8 & .65 & .48 & .39 & -4.218 & .000 \\
\hline 9 & .66 & .48 & .50 & -5.508 & .000 \\
\hline 10 & .45 & .50 & .32 & -2.909 & .006 \\
\hline 11 & .48 & .50 & .34 & -3.307 & .002 \\
\hline 12 & .60 & .49 & .38 & -3.878 & .000 \\
\hline 13 & .59 & .49 & .40 & -4.816 & .000 \\
\hline 14 & .73 & .45 & .34 & -3.623 & .001 \\
\hline $15^{*}$ & .57 & .50 & .25 & -1.845 & .072 \\
\hline 16 & .38 & .49 & .41 & -3.789 & .000 \\
\hline 17 & .44 & .50 & .45 & -4.816 & .000 \\
\hline 18 & .47 & .50 & .53 & -6.355 & .000 \\
\hline 19 & .45 & .50 & .52 & -6.355 & .000 \\
\hline 20 & .73 & .45 & .34 & -3.474 & .001 \\
\hline 21 & .70 & .46 & .32 & -3.378 & .002 \\
\hline 22 & .73 & .45 & .34 & -3.474 & .001 \\
\hline 23 & .67 & .47 & .34 & -3.789 & .000 \\
\hline 24 & .72 & .45 & .37 & -4.320 & .000 \\
\hline 25 & .70 & .46 & .37 & -4.320 & .000 \\
\hline 26 & .58 & .50 & .48 & -5.384 & .000 \\
\hline 27 & .57 & .50 & .48 & -5.384 & .000 \\
\hline 28 & .58 & .50 & .51 & -6.148 & .000 \\
\hline 29 & .58 & .50 & .46 & -5.715 & .000 \\
\hline 30 & .56 & .50 & .42 & -4.947 & .000 \\
\hline 31 & .57 & .50 & .43 & -4.947 & .000 \\
\hline 32 & .49 & .50 & .40 & -4.754 & .000 \\
\hline 33 & .50 & .50 & .44 & -5.384 & .000 \\
\hline 34 & .52 & .50 & .41 & -4.816 & .000 \\
\hline 35 & .52 & .50 & .43 & -5.384 & .000 \\
\hline 36 & .31 & .46 & .59 & -6.355 & .000 \\
\hline 37 & .27 & .45 & .41 & -4.245 & .000 \\
\hline 38 & .25 & .44 & .54 & -5.508 & .000 \\
\hline 39 & .28 & .45 & .56 & -6.708 & .000 \\
\hline 40 & .27 & .45 & .58 & -5.715 & .000 \\
\hline 41 & .86 & .35 & .35 & -3.813 & .000 \\
\hline 42 & .90 & .31 & .34 & -3.130 & .003 \\
\hline 43 & .85 & .36 & .39 & -4.183 & .000 \\
\hline 44 & .51 & .50 & .64 & -9.721 & .000 \\
\hline 45 & .36 & .48 & .60 & -9.721 & .000 \\
\hline 46 & .35 & .48 & .56 & -8.450 & .000 \\
\hline 47 & .38 & .49 & .64 & -11.53 & .000 \\
\hline 48 & .43 & .50 & .49 & -6.052 & .000 \\
\hline 49 & .52 & .50 & .65 & -9.721 & .000 \\
\hline
\end{tabular}

Matematik Başarı Testinin Geliştirilme Süreci: Çalışmada, araştırmacılar tarafından geliştirilen "Matematik Başarı Testi” uygulanmıştır. Bu bağlamda, test soruları, 2015 ilkokul matematik dersi öğretim program üçüncü sınıf kesirler konu alanını kapsayan kazanımlara uygun olarak seçilmiştir. Seçilen soruların kapsam geçerliğine uygunluğu bir devlet üniversitesinde matematik eğitimi alanında uzman 
üç öğretim üyesi, yüksek lisans yapan iki matematik öğretmeni ve Milli Eğitim Bakanlığına bağlı ilkokullarda çalışan üç sınıf öğretmeni tarafından da sınanmıştır. Bir sonraki aşamada ise geliştirilen başarı testi sosyo -ekonomik düzey ve akademik başarı açısından birbirine denk iki okuldan 88 dördüncü sınıf öğrencisine pilot olarak uygulanmıştır. $\mathrm{Bu}$ kapsamda, madde analizine ilişkin bulgular Tablo 2'de verilmiştir.

Tablo 2'de 49 sorunun madde güçlük derecesi (pj), standart sapması (sj), ayırıcılık indisi (rjx) ve alt ve üst gruplar \%27'lik dilimler için bağımsız gruplar t-testi değerleri yer almaktadır. Bu analizler sonucunda, $\mathrm{p}$ değeri .05'in üstü olan 15 numaralı soru, testten çıkarılmıştır. Buna göre başarı testinin son hali 48 sorudan oluşmaktadır. Uygulanan başarı testinin aritmetik ortalamas1 10,10 ;standart sapmas1 7.03 ve KR-20 değeri .81 olarak bulunmuştur. Hazırlanan matematik başarı testinin güvenirliği yeterli görülmüş ve öğrencilere ön test ve son test olarak uygulanmıştır. $\mathrm{Bu}$ soruların kazanımlara göre dağılımları Tablo 3 'te gösterilmiştir.

Tablo 3. Kesirler Konusu Kazanımlarının Matematik Başarı Testindeki Dağılımları

\begin{tabular}{ll}
\hline Kazanımlar & Sorular \\
\hline $\begin{array}{l}\text { Bir bütünü eş parçalara ayırarak kesrin } \\
\text { birimi olduğunu belirtir }\end{array}$ & $\begin{array}{l}1,2,3,4,26,27,28, \\
29,30,31,32,33,34, \\
35,36\end{array}$ \\
\hline $\begin{array}{l}\text { Paydası payından küçük ve paydası en } \\
\text { çok iki basamaklı doğal sayı olan kesir } \\
\text { elde eder. }\end{array}$ & $\begin{array}{l}5,6,7,8,9,10,11,12, \\
13,14,19,20,21,22\end{array}$ \\
\hline $\begin{array}{l}\text { Paydası en çok iki basamaklı doğal sayı } \\
\text { olan en çok üç kesri, karşılaştırır ve }\end{array}$ & $23,24,25,37,38,39$, \\
siralar. & 40,41 \\
\hline $\begin{array}{l}\text { Birçokluğun belirtilen kesrin birimi } \\
\text { kadarını belirler. }\end{array}$ & $15,16,17,18,42,43$, \\
\end{tabular}

Tablo 3'te kesirler konusuyla ilgili kazanımların matematik başarı testindeki sorulara göre dağılımı görülmektedir. İlk olarak "Bir bütünü eş parçalara ayırarak kesrin birimi olduğunu belirtir" kazanımına ilişkin on beş soru; ikinci olarak "Paydası payından küçük ve paydası en çok iki basamaklı doğal sayı olan kesir elde eder" kazanımına ilişkin on dört soru; üçüncü olarak "Paydası en çok iki basamaklı doğal sayı olan en çok üç kesri, karşılaştırır ve sıralar" kazanımına ilişkin sekiz soru ve son olarak "Birçokluğun belirtilen kesrin birimi kadarını belirler" kazanımına ilișkin ise on bir soru bulunmaktadır. Hazırlanan soruların $15{ }^{\prime} i$ "bilgi"; 15'i "kavrama" ve diğer 19'u ise "uygulama" düzeyindedir. Bu kategori bilgi düzeyinde "Kesirin tanımını yapınız"; kavrama düzeyinde "Sekiz tane çeyrek kaç tane bütün eder?. açıklayınız" ve uygulama düzeyinde ise " $3 / 7$, $5 / 7,4 / 7$ ve $2 / 7$ kesirlerini küçükten büyüğe doğru sıralayınız." biçiminde sorulardan oluşmuştur.

Matematik Tutum Ölçeği: Araştırmada Baykul'un (1990) geliştirdiği "Matematik Tutum Ölçeği” öğrencilerin matematiğe ilişkin tutumlarını ölçmede uygulanmıştır. Yapılan faktör analizi sonuçlarına göre, tek faktörle açıklanabilen ölçeğin varyans oranı 0,56 olarak bulunmuştur. Ayrıca ölçeğin son halinde 15'i olumlu ve 15'i olumsuz olan toplam 30 madde yer almaktadır. Ölçekteki maddeler; "Tamamen katıliyorum", "Genellikle katılıyorum", "Kararsızım", "Katılmıyorum" ve "Asla katılmıyorum" şeklinde beşli likert tipinde derecelendirilmiştir (Baykul, 1990). Bu örneklem için uygulanan ölçeğin Cronbach alfa iç güvenirlik katsayısı .72'dir.

Öğrenme Stilleri Ölçeği: Öğrenme Stilleri Ölçeği, Gökdağ (2004) tarafından geliştirilen üç faktörden oluşan 28 maddelik bir ölçektir. Ölçeğin faktör çözümlemesinde faktör yükü 0.40 'ın üstünde olan maddeler seçilmiştir. Ölçek üç faktörden (işitsel, görsel ve hareketsel) oluşmaktadır. Beşli likert tipinde olan ölçekteki maddelerin tümü olumlu cümleler içermektedir. Öğrenme stilli ölçeğinin 13 maddesi görsel, 10 maddesi kinestetikve kalan beş maddesi ise işitsel öğrenme stilinden oluşmaktadır. Beşli likert tarzında hazırlanan ölçekten alınabilecek puanlar 28 ile 140 arasında değişmektedir (Eskici, 2008). Araştırmada, deneysel işlem süreci kapsamında öğrencilere öğrenme stillerine göre grup halinde etkinlikler uygulatılmıştır. Bu bağlamda, deney grubunda yer alan öğrencilerin öğrenme stillerinin neler olduğunu saptamak üzere öğrenme stilleri ölçeği uygulanmıştır. Buna göre öğrencilerin öğrenme stillerine ilişkin dağılımları Tablo 4'te yer almaktadır.

Tablo 4. Deney Grubu Öğrencilerine Uygulanan Öğrenme Stilleri Ölçeği Sonuçları

\begin{tabular}{lccc}
\hline & $\begin{array}{c}\text { Görsel } \\
\text { Öğrenme } \\
\text { Stili }\end{array}$ & $\begin{array}{c}\text { İşitsel } \\
\text { Ögrenme } \\
\text { Stili }\end{array}$ & $\begin{array}{c}\text { Kinestetiksel } \\
\text { Öğrenme Stili }\end{array}$ \\
\hline Kizlar & 4 & 2 & 8 \\
Erkekler & 2 & 1 & 3 \\
\hline Toplam & 6 & 3 & 11 \\
\hline
\end{tabular}

Tablo 4'te görüldüğü gibi “Görsel Öğrenme Stili”ni kızlardan dört, erkeklerden iki öğrenci; "İşitsel Öğrenme Stili”ni kızlardan iki erkeklerden bir öğrenci; "Kinestetiksel Öğrenme Stili" ni ise kızlardan sekiz, erkeklerden ise üç öğrenci tercih etmektedir.

\subsection{Verilerin Toplanmas1}

Verilerin toplanması sürecinde, çalışma, 2015-2016 eğitimöğretim yılı ikinci döneminde yaklaşık dört haftalık bir süre içerisinde gerçekleştirilmiştir. $\mathrm{Bu}$ deneysel çalışma sürecinde izlenen yollar aşağıda madde halinde belirtilmiştir.

(i) 2015-2016 eğitim-öğretim yılının ikinci döneminde yaklaşık dört haftalık süre içerisinde uygulanmıştır.

(ii) Katılımcılar 2015-2016 eğitim-öğretim yılının ikinci döneminde, Adana ili Ceyhan ilçesindeki, bir resmi ilkokulunda bulunan üçüncü sınıf öğrencilerinden oluşmaktadır. Deney grubu araştırmacıların hazırladığı program çerçevesinde farklılaştırılmış öğretim yaklaşımını aynı zamanda sınıf öğretmeni olan araştırmacılardan biri tarafından uygularken, kontrol grubuna hiç müdahale edilmeden mevcut eğitimle mevcut derslerin yürütülmesi sağlanmıştır.

(iii) Farklılaştırılmış öğretim yaklaşımının uygulanacağı deney grubundaki öğrencilerin ve mevcut eğitimin uygulanacağı kontrol grubundaki öğrencilerin hazırbulunuşluk seviyelerini öğrenmek ve sonrasında veri analiz sürecinde kullanılacak olan kesirler öğrenme dâhilindeki konuları kapsayan "Matematik Başarı Testi” ve "Matematik Tutum Ölçeği” ön test olarak uygulanmıştır.

(iv) Deneysel süreç başlamadan önce öğrencilerin bu grupta yer alan öğrencilere "Öğrenme Stilleri Ölçeği”" 
uygulayarak hangi öğrencinin hangi öğrenme stilinde yer alacağı belirlenmiştir ve etkinlikler bu süreçte planlanmıştır.

(v) Deney grubundaki öğrencilerin derse karşı tutumlarını, hazırbulunuşluk seviyelerini ve öğrenme stillerini ögrendikten sonra eldeki verilere göre ders planları ve çalışma kâğıtları hazırlanmıştır. Derslerin planlanması ve çalışma kâğıtlarının hazırlanmasında; farklılaştırılmış öğretim yaklaşımınlarından katlı öğretim tekniği kullanılmış ve ders planlarının uygunluğu uzman görüşüne sunulmuştur. Katlı öğretim, öğrencilerin ön öğrenmeleri, öğrenme hızları, ilgileri, bilişsel yetenekleri ve öğrenme stillerinin farklılaşmasında kullanılabilir. Bu şekilde ön öğrenmesi düşük, orta ve yüksek olan öğrencilerin aynı konuları, kendilerine uygun zorluk seviyesinde öğrenmeleri sağlanmaktadır (Tomlinson 1999). Bu bağlamda, öncelikle konunun özellikleri, kazanımlar ve beceriler sınıf öğretmeni olan araştırmacılardan biri tarafından deney grubundaki öğrencilere anlatılmıştır. Sonra katlı öğretim tekniği kapsamında öğrencilerin hazırbulunuşluklarına ve öğrenme stillerine göre bireysel ya da gruplar oluşturulmuştur (Gregory ve Chapman, 2002; Tomlinson, 1999). Bu aşamada, hazırbulunuşluk düzeyi yüksek olan öğrencilere yüksek, orta düzeydeki öğrencilere orta ve düşük düzeydeki öğrencilere ise alt öğrenme basamağına uygun etkinlikler verilmiştir. Diğer taraftan ise, öğrenme stillerine göre" görsel", "işitsel" ya da "kinestetik" öğrenme stiline sahip olan öğrencilere yönelik etkinlikler yaptırılmıştır. Kontrol grubunun ise, mevcut eğitim kapsamında ders işleme sürecine ve ders planına devam edilmiştir.

(vi) Farklılaştırılmış öğretim yaklaşımının uygulandığı deney grubunda ve mevcut eğitimin uygulandığ 1 kontrol grubunda kesir konusunun işlenmesinden sonra son test olarak "Matematik Başarı Testi" ve "Matematik Dersi Tutum Ölçeği” uygulanmıştır.

\subsection{Verilerin Analizi}

Araştırmada, nicel verilerin analizi kapsamında betimsel istatistik, kay kare ve bağımsız gruplar t testi analizleri yapılmıştır. Verilerin yorumlanmasında ise $\mathrm{p}=0,05$ anlamlılık düzeyi kabul edilmiştir.

\section{Bulgular}

$\mathrm{Bu}$ bölümde, araştırma soruları bağlamında elde edilen verilerin istatistiksel çözümlemeleri ve elde edilen bulgular yer almaktadır.

Araştırmada, ilk alt amaç olarak farklılaştırılmış öğretim yaklaşımının uygulandığı deney grubu ile mevcut öğretimin uygulandığ1 kontrol grubundaki öğrencilerin, ön test puanları arasında istatistiksel olarak anlamlı bir fark olup olmadığına bakılmıştır. $\mathrm{Bu}$ amaçla, uygulanan bağımsız gruplar t testi sonuçları Tablo 5 'te yer almaktadır.

Tablo 5. Öğrencilerin Ön Test Akademik Başarıları Puanlarına İlişkin Bağımsız Gruplar t-Testi Analizi Sonuçları

\begin{tabular}{lcccccc}
\hline Gruplar & $\mathrm{N}$ & $\mathrm{X}$ & $\mathrm{S}$ & $\mathrm{sd}$ & $\mathrm{t}$ & $\mathrm{p}$ \\
\hline Deney Grubu & 20 & 10.85 & 8.42 & \multirow{2}{*}{38} & \multirow{2}{*}{.670} & \multirow{2}{*}{.508} \\
\hline Kontrol Grubu & 20 & 9.35 & 5.41 & & & \\
\hline
\end{tabular}

Buna göre Tablo 5 incelendiğinde deney grubu matematik başarı testinin aritmetik ortalaması 10,85 iken, kontrol grubu matematik başarı testinin aritmetik ortalaması ise 9,35'dir. $\mathrm{Bu}$ bağlamda, deney grubu ile kontrol grupları arasında akademik başarı değişkenleri açısından istatistiksel olarak anlamlı bir fark olmadığ 1 açıkça görülmektedir.

Araştırmada, ikinci alt amaç olarak farklılaştırılmış öğretim yaklaşımının uygulandığı deney grubu ile mevcut öğretimin uygulandığı kontrol grubundaki öğrencilerin, son test puanları arasında istatistiksel olarak anlamlı bir fark olup olmadığına bakılmıştır. Bu amaçla, uygulanan bağımsız gruplar t testi sonuçları Tablo 6'da yer almaktadır.

Tablo 6. Öğrencilerin Son Test Akademik Başarıları Puanlarına İlişkin Bağımsız Gruplar t-Testi Analizi Sonuçları

\begin{tabular}{lcccccc}
\hline Gruplar & $\mathrm{N}$ & $\mathrm{X}$ & $\mathrm{S}$ & $\mathrm{sd}$ & $\mathrm{t}$ & $\mathrm{p}$ \\
\hline Deney Grubu & 20 & 36.20 & 10.62 & \multirow{2}{*}{38} & \multirow{2}{*}{4,195} & \multirow{2}{*}{00} \\
\hline Kontrol Grubu & 20 & 22,6 & 9.87 & & & \\
\hline
\end{tabular}

Tablo 6 incelendiğinde deney grubu matematik başarı testinin aritmetik ortalaması 36.2 iken, kontrol grubu matematik başarı testinin aritmetik ortalaması ise 22.6' dır. $\mathrm{Bu}$ bağlamda, deney grubuyla kontrol grupları arasında akademik başarı değişkenleri açısından deney grubu lehine istatistiksel olarak anlamlı bir fark olduğu görülmektedir.

Araştırmada, üçüncü alt amaç olarak farklılaştırılmış öğretim yaklaşımının uygulandığı deney grubu ile mevcut öğretimin uygulandığı kontrol grubundaki öğrencilerin, ön test tutum puanları arasında istatistiksel olarak anlamlı bir fark olup olmadığına bakılmıştır. Bu amaçla, uygulanan bağımsız gruplar t testi sonuçları Tablo 7'de yer almaktadır.

Tablo 7. Öğrencilerin Matematiğe Yönelik Ön Test Tutum Ölçeği Puanlarına İlişkin Bağımsız Gruplar t-Testi Analizi Sonuçları

\begin{tabular}{lcccccc}
\hline Gruplar & $\mathrm{N}$ & $\mathrm{X}$ & $\mathrm{S}$ & $\mathrm{sd}$ & $\mathrm{t}$ & $\mathrm{p}$ \\
\hline $\begin{array}{l}\text { Deney Grubu } \\
\text { Kontrol }\end{array}$ & 20 & 92.80 & 16.05 & & & \\
Grubu & 20 & 91.05 & 13.40 & 38 & .374 & .710 \\
\hline
\end{tabular}

Tablo 7 incelendiğinde, deney grubundaki öğrencilerin matematiğe yönelik ön test tutum ölçeği puanının aritmetik ortalamas1 92.80 iken, kontrol grubu matematik tutum testinin aritmetik ortalaması ise 91.05 'dir. Bu kapsamda, deney grubunda ve kontrol grubunda yer alan öğrencilerin matematik dersine yönelik tutumlarının birbirine yakın olduğu ve istatistiksel olarak aralarında anlamlı bir fark olmadığı sonucuna ulaşılmıştır.

Araştırmada, son alt amaç olarak farklılaştırılmış öğretim yaklaşımının uygulandığı deney grubu ile mevcut öğretimin uygulandığı kontrol grubundaki öğrencilerin, son test tutum puanları arasında istatistiksel olarak anlamlı bir fark olup olmadığına bakılmıştır. Bu amaçla, uygulanan bağımsız gruplar t testi sonuçları Tablo 8'de yer almaktadır.

Tablo 8. Öğrencilerin Matematiğe Yönelik Son Test Tutum Ölçeği Puanlarına İlişkin Bağımsız Gruplar t-Testi Analizi Sonuçları

\begin{tabular}{lcccccc}
\hline Gruplar & $\mathrm{N}$ & $\mathrm{X}$ & $\mathrm{S}$ & $\mathrm{sd}$ & $\mathrm{t}$ & $\mathrm{p}$ \\
\hline Deney Grubu & 20 & 92.60 & 16.96 & \multirow{2}{*}{38} & - & \multirow{2}{*}{963} \\
Kontrol Grubu & 20 & 92.85 & 17.04 & & .04 & \\
\hline
\end{tabular}

Tablo 8 incelendiğinde, deney grubundaki öğrencilerin matematiğe yönelik son test tutum ölçeği puanının aritmetik ortalamas1 92.60 iken, kontrol grubu matematik tutum 
testinin aritmetik ortalaması ise 92.85 'dir. Bu kapsamda, deney grubunda ve kontrol grubunda yer alan öğrencilerin matematik dersine yönelik tutumlarının birbirine yakın olduğu ve istatistiksel olarak aralarında anlamlı bir fark olmadığı sonucuna ulaşılmıştır.

\section{Tartışma, Sonuç ve Öneriler}

$\mathrm{Bu}$ çalışma farklılaştırılmış öğretim yaklaşımının öğrencilerin akademik başarıları ve tutumları üzerine etkisini belirlemek amacıyla yapılmıştır. Araştırmada farklılaştırılmış öğretim yaklaşımının uygulandığı deney grubundaki öğrencilerin son testden aldıkları puanlar kontrol grubundaki ögrencilere göre daha yüksek olduğu bulgusuna ulaşılmıştır. Buna göre farklılaştırılmış öğretim yaklaşımının öğrencilerin matematik başarılarını artırdığı söylenebilir sonucuna ulaşılmıştır. Çalışmadan elde edilen bu bulgu ilgili literatürle paralellik göstermektedir (Beler ve Avc1 (2011), Boerger (2005), Bosier (2007) Demir (2016), Chamberlin ve Powers (2010), Luster (2008), Kök (2012), Karaduman (2012), Richards ve Omdal (2007), Özyaprak (2012), Sondergeld ve Schultz (2008), Springer, Pugalee ve Algozzine (2007), Stager (2007), Şaldırak (2012), Yabaş ve Altun (2009), Yabaş (2008). Bu bağlamada örneğin Boerger (2005) farklılaştırılmış öğretim yaklaşımının uygulandığı matematik sınıflarında öğrencilerin akademik başarılarının gözle görülür derecede arttığı sonucuna ulaşmıştır.

Öte yandan, araştırma bulgularına göre farklılaştırılmış öğretim yaklaşımının uygulandığı deney grubundaki öğrencilerle, mevcut öğretim uygulamalarının kullanıldığı kontrol grubundaki ögrrencilerin tutum puanları arasında istatistiksel olarak anlamlı bir fark olmadığı bulgusuna ulaşılmıştır. Araştırmaya katılan hem deney hem de kontrol grubundaki öğrencilerin mevcut tutumlarının değişmemesine neden olarak tutum değişkeninin duyuşsal bir içeriğe sahip olması ve daha uzun zaman alması gösterilebilir. (Arseven, 2010; Baykul, 1990). Diğer bir neden ise deneysel çalışmanın uygulandığı öğrencilerin küçük yaş grubunda olması şeklinde değerlendirilebilir (Topan, 2013). Ancak, literatürde bu çalışmanın sonuçlarından farklı bulguları işaret eden deneysel çalışmalara da rastlanmaktadır. Bu çalışmalarda ulaşılan bulgular ise farklılaştırılmış öğretim yaklaşımının uygulandığı sınıflardaki öğrencilerin derse yönelik olumlu tutumlar geliştirdiklerini göstermektedir (Boerger, 2005; Bosier, 2007; Karataş, 2013; Özyaprak, 2012). Bu durum örneklemden, konudan ya da deneysel süreden kaynaklanabilir.

Sonuç olarak, farklılaştırılmış öğretim yaklaşımının öğrencilerin akademik başarıları ve tutumları üzerine etkisini belirlemek amacıyla yapılan bu çalışma ile öğrencilerin akademik başarılarının arttığı ancak tutumlarında bir değişim olmadığı sonucuna ulaşılmıştır. $\mathrm{Bu}$ çalışma matematik dersinde kesirler ünitesinde uygulanmıştır. Ancak, benzer bir araştırma farklı bir ders kapsamında ya da matematik dersinin faklı bir konusunda da yapılabilir. Ayrıca farklılaştırılmış öğretim yaklaşımı konusunda öğrencilerin ve öğretmenlerin görüşlerine de yer verilerek izlenen süreç daha derinlemesine irdelenebilir.

Ancak, literatürde bu çalışmanın sonuçlarından farklı bulguları işaret eden deneysel çalışmalara da rastlanmaktadır $\mathrm{Bu}$ çalışmalarda ulaşılan bulgular ise farklılaştırılmış öğretim yaklaşımının uygulandığı sınıflardaki öğrencilerin derse yönelik olumlu tutumlar geliștidiklerini göstermektedir (Boerger, 2005; Bosier, 2007; Karataş, 2013; Özyaprak, 2012).

Sonuç olarak, farklılaştırılmış öğretim yaklaşımının öğrencilerin akademik başarıları ve tutumları üzerine etkisini belirlemek amacıyla yapılan bu çalışma ile öğrencilerin akademik başarılarının arttığı ancak tutumlarında bir değişim olmadığı sonucuna ulaşılmıştır. Bu bilgiler 1şı ğında bu çalışma matematik dersinde kesirler ünitesinde uygulanmıştır. Ancak, benzer bir araştırma farklı bir ders kapsamında ya da matematik dersinin faklı bir konusunda da yapılabilir. Ayrıca farklılaştırılmış öğretim yaklaşımı konusunda öğrencilerin ve öğretmenlerin görüşlerine de yer verilerek izlenen süreç daha derinlemesine irdelenebilir.

\section{Kaynakça}

Abbati, D. G. (2012). Differentiated instruction: understanding the personal factors and organizational conditions that facilitate differentiated instruction in elementary mathematics classrooms. Doctoral Disertations. Berkeley: University Of California.

Açıkgöz, Ü. K. (2003). Aktif öğrenme (4. bs.). İzmir: Eğitim dünyası yayınları.

Arıkan, E. E., \& Ünal, H. (2013). İlköğretim 2. sınıf öğrencilerinin matematiksel problem kurma becerilerinin incelenmesi. Amasya Üniversitesi Eğitim Fakültesi Dergisi, 2(2), 305-325,

Arseven, A. (2010). Gerçekçi matematik öğretiminin bilişsel ve duyuşsal ögrenme ürünlerine etkisi. Doktora Tezi. Ankara: Hacettepe Üniversitesi.

Aydın, G. N. (2014). Gerçekçi matematik eğitiminin ilkokul 3. Sinıf ögrencilerine kesirlerin ögretiminde başarlya kalıcılı̆̆a ve tutuma etkisi. Yüksek Lisans Tezi. Bolu: Abant İzzet Baysal Üniversitesi.

Baykul, Y. (1990). Illkokul beşinci sınıftan lise ve dengi okulların son sinuflarına kadar matematik ve fen derslerine karşı tutumda görülen değişmeler ve ögrenci yerleştirme sinavindaki başarl ve ilişkili olduğu düşünülen bazı faktörler. Ankara: ÖSYM Yayınları.

Beler, Y., \& Avcı, S. (2011). Öğretimin farklılaştırılmasında etkili bir strateji: katlı öğretim. Ahi Evran Üniversitesi Eğitim Fakültesi Dergisi, 12(3), 109-126.

Boerger, M. V. (2005). Differentiated instruction in the middle school math classroom: A case study. Yüksek Lisan Tezi. Pacific Lutheran University.

Bosier, C. S. (2007). The effects of teacher perception of differentiated mathematical instruction on student achievement. Doctoral Disertations. Canada: University of Capella, Minneapolis.

Chamberlin, M., \& Powers, R. (2010). The promise of differentiated instruction for enhancing the mathematical understandings of college students. Teaching Mathematics and Its Applications, 29, 113-139.

Christensen, L. B., Johnson, R. B., \& Turner, L. A. (2015). Research methods design and analysis. (Çev. Ed. A. Aypay). Ankara: Anı Yayın. 
Christensen, S., M. (2007). Differentiated instruction and motivation with highly capable primary students: Case studies within two math units. Master's Thesis. Washington: University Of Pacific Lutheran.

Demir, S. (2016) Katlı öğretim yönteminin öğrencilerin akademik başarı puanları, öğrenme yaklaşımları ve öğrenmenin kalıcılığı üzerindeki etkisi. Kastamonu Ĕ̈itim Dergisi, 24(4), 1589-1602.

Demirel, Ö. (2006). Eğitimde program geliştirme (10 bs.). Ankara: Pegem A Yayıncılık.

Ericson, C. (2010). Differentiated instruction: Applying the work of $C$. A. Tomlinson in the primary literacy classroom. Master's Thesis. British Columbia: University Of Victoria.

Eskici, M. (2008). Öğrencilerin ögrenme stilleri ile akademik başarlarıve cinsiyetleri arasındaki ilişki. Yüksek Lisans Tezi. Edirne: Trakya Üniversitesi.

Good, M. E. (2006). Differentiated instruction: Principles and techniques for the elementary grades. Master's Thesis. , California: University of Californi.

Gregory, G. H., \& Chapman, C. (2002). Differentiated instructional strategies: One size doesn't fit all. Thousand Oaks, CA: Corwin Press.

Hall, T., Strangman, N., \& Meyer, A. (2003). Differentiated instruction and implications for UDL implementation. Wakefield, MA: National Center on Accessing the General Curriculum. (Aceessed on August 20, 2006), http://www.cast.org/publications/ncac/ncac_diffinstruct udl.html

Karaduman, G. (2012). Ilköğretim 5. sinıf üstün yetenekli öğrenciler için farklılaştırılmış geometri öğretiminin yaratıcı düşünme, uzamsal yetenek düzeyi ve erişiye etkisi. Doktora Tezi. İstanbul: İstanbul Üniversitesi.

Karasar, N. (1999). Bilimsel araştırma yöntemi (9. bs.). Ankara: Nobel Dağıtım.

Karataş, D.Y. (2013). Farklılaştırılmış matematik ögretiminin üstün zekâll ve yetenekli ögrencilerde erişiye, yaratıcılı̆̆a, tutuma ve akademik benliğe etkisi. Doktora Tezi. İstanbul: İstanbul Üniversitesi.

Kart, C. (2002). Matematik eğitimi ve öğretimi. Çăgdaş Ë̆itim Dergisi, 27, 291.

Kök, B. (2012). Üstün zekâll ve yetenekli öğrencilerde farklılaştırılmış geometri ögretiminin yaratıcılı̆̆a, uzamsal yeteneğe ve başarlya etkisi. Doktora Tezi. İstanbul: İstanbul Üniversitesi.

Lawrence-Brown, D. (2004). Differentiated instruction: Inclusive strategies for standards-based learning. American Secondary Education, 32 (3), 34-62.

Levy, H. M. (2008). Meeting The Needs Of All Students Through Differentiated Instruction: Helping Every Child Reach And Exceed Standards. The Clearing House, 81(4), 161-164.

Luster, R. (2008). A quantitative study investigating the effects of whole-class and differentiated instruction on student achievement. PhD Thesis. Walden University.
Millikan, S. D. (2012). Teachers' perceptions of theuse of differentiated instruction on student achievement in mathematics. $\mathrm{PhD}$ Thesis. Minneapolis, Canada: University of Walden.

Özyaprak, M. (2012). Üstün zekâlı ve yetenekli ögrencilere yönelik farklılaştırılmış matematik ögretiminin erişi, tutum ve yaratıcilı̆̆a etkisi. Doktora Tezi. İstanbul: İstanbul Üniversitesi.

Richards, M. R. E., \& Omdal, S. N. (2007). Effects Of Tiered İnstruction On Academic Performance İn A Secondary Science Course. Journal Of Advanced Academics, 18(3), 424-456.

Senemoğlu, N. (2002). Gelişim, öğrenme ve ögretim (1. bs.). Ankara: Gazi Kitapevi.

Sondergeld, T. A., \& Schultz, R. A. (2008). Science, Standards, And Differentiation: It Really Can Be Fun!. Gifted Child Today, 31(1), 34-40.

Springer, R., Pugalee, D., \& Algozzine, B.(2007). Improving mathematics skills of high school students. The Clearing House, (81)37-43

Stager, A. (2007). Differentiated instructimn in mathematics. Master Thesis. New Jersey: University Of Caldwell College.

Şaldırdak, B. (2012). Farklılaştırılmış öğretim uygulamalarının matematik başarısına etkisi. Yüksek Lisans Tezi. Ankara: Ankara Üniversitesi.

Tomlinson, C. A. (1999). Educational leadership. Personalized Learning, 57(1), 12-16.

Tomlinson, C. A. (1999). The differentiated classroom: Responding to the needs of all learners. USA, Alexandria, VA: Association for Supervision and Cirriculum Development.

Tomlinson, C. A. (2000). Differentiation of Instruction in the Elementary Grades. ERIC Digest. (Accessed on 10/10/2018),

http://education.ky.gov/educational/diff/Documents/tom lin00.pdf

Topan, B. (2013). Matematik ögrretiminde ögrrenci merkezli yöntemlerin akademik başarı ve derse yönelik tutum üzerindeki etkililiği: Bir meta-analiz çallşması. Yüksek Lisans Tezi. Kocaeli: Kocaeli Üniversitesi.

Uygun, N., \& Tertemiz, N.I (2014). Matematik dersinde probleme dayalı öğrenmenin öğrencilerin derse ilişkin tutum, başarı ve kalıcılık düzeylerine etkisi. Eğitim ve Bilim, 39(174), 75-90.

Yabaş D., \& Altun, S. (2009). Farklılaştırılmış öğretim tasarımının öğrencilerin özyeterlik algıları, bilişüstü becerileri ve akademi başarılarına etkisinin incelenmesi. Hacettepe Üniversitesi Eğitim Fakültesi Dergisi, 37, 201-214.

Yabaş, D. (2008). Farklılaştırılmış öğretim tasarımının öğrencilerin özyeterlik algıları, bilişüstü becerileri ve akademik başarılarına etkisinin incelenmesi. Yüksek Lisans Tezi. İstanbul: Yıldız Teknik Üniversitesi. 